\title{
Sharing the Economic Torment due to COVID - 19 and Pertinent Behavioural Biases on Financial Risk Resilience Ability of Security Market Investors
}

\author{
Nidhi Jain ${ }^{1 *}$ and Dr Bikrant Kesari ${ }^{2}$ \\ 1,2 Maulana Azad National Institute of Technology, Bhopal, Madhya Pradesh 462003, India. \\ Email: ${ }^{*}$ nidhiphdmanit@gmail.com, ${ }^{2}$ bikrantkesari@gmail.com \\ *corresponding author
}

\begin{abstract}
Behavioural inclinations depict a replicable example in perceptual mutilation, mistaken judgment, unreasonable understanding, or what is extensively called mindlessness. This paper embraces an essential information way to deal with explore the impacts of behavioural predispositions due to Covid-19 on security market performance in India. The destinations are in twofold: one, to analyze the degree of behavioural predispositions among security market investors in India and, to look at the impacts of social inclinations on securities market in India. The paper utilized questionnaire as instrument and the strategy of correlation with Pearson Coefficient to examine a review of 150 haphazardly chose investors in India's security market. There is a solid proof that behavioural inclinations exists overwhelmingly due to COVID - 19 in the security market in light of the fact that a feeble negative relationship exists between social predispositions and securities exchange market in India. The biases due to behaviour include Confirmation bias, Reducing Regret bias, Myopic loss-aversion bias, Limited attention span bias, Chasing Trends bias and Status quo bias. The paper suggests that individual financial specialists in the market ought to connect with the administrations of investment advisors which will diminish individual inclinations in the administration of their portfolios.
\end{abstract}

Keywords: Bias, Behaviour, Security Market, Market Performance, Financial Resilience

\section{INTRODUCTION}

Researchers in the field of behavioural finance have gathered a great collection of investigation proposing that people don't act sanely constantly when settling on investment choices. These discoveries have critical ramifications for the advancement of the securities market. The Indian security market has pulled out of the 2008/2009 great depression and it is moderately steady now, however the steadiness of things to come showcase is reliant on the dynamic examples of individual just as institutional investors who exchange day by day in the market. Economic and financial theories are worked around the key presumptions that people are rational specialists who consistently carry on in a sensible manner, thinking about completely related data before deciding, and with steady and predictable inclinations after some time. Traditional financial aspects characterize sanity legitimately, for example, if an individual loves $\mathrm{A}$ superior than $\mathrm{B}$ and $\mathrm{B}$ superior to $\mathrm{C}$, a market analyst would reason that the individual inclines toward $\mathrm{A}$ to $\mathrm{C}$, however this may not be so, all things considered, circumstance, particularly with money related investment.

Despite the fact that the field of Economics has propounded numerous speculations throughout the years on human conduct, it has not had the option to clarify why 
individuals routinely settle on money related choices that are silly. There have been studies in the field of finance that clarify and demonstrate the manner in which financial markets work, there are likewise examines that causes us to comprehend the elements behind investments whereupon numerous standards have been planned. In spite of the fact that these principles on investment are basic, most financial specialists experience difficulty reliably applying them. This prompts most financial specialists either exchanging excessively, purchase and sell at definitely an inappropriate occasion, permit feelings to overrule rationale, misconstrue probabilities, or uselessly pursue performance.

Behavioural Finance recognizes two essential reasons which make investors to carry on semi normally. The first is on the grounds that investors are human and really want to encounter a scope of feelings as investments costs move. These enthusiastic responses can unintentionally strife with levelheaded personalities to contort the way market exercises are seen or misperceived. For example, however it is comprehended that it is superbly typical for investments to move in cycles, financial specialists feel energized and euphoric when a investment is producing solid returns in the better than expected piece of its cycle - which starts an amazing inclination to purchase when markets are high as opposed to following monetary hypothesis to purchase when market is low. In the lower some portion of an investment cycle, poor returns make diverse view. Financial specialists become gloomy, on edge and panicky, and would naturally look to end the upsetting experience by selling when they ought to purchase. All things considered; investors are enticed to supplant these holdings with assets which cause them to feel energized. In this manner selling low and purchasing high - albeit objectively it is comprehended that the best financial opportunities happen at market bottoms, and risk is most noteworthy when investment cycles are at their pinnacle. In this manner, rationale and feelings are in struggle.

The second region of irrationality has its underlying foundations in human intellectual components. Human view of issues has grown quick and shaped successful procedures to quickly deal with information and speed our choices. While these are amazingly valuable in numerous everyday issues, they can cut off choices in venture. When investing we're naturally constrained to face a bigger number of challenges to stay away from misfortunes than to accomplish gains. These counter responses change the market and retard improvement in the security market on the grounds that we unwittingly become hopeful in a high market and negative in a low market.

Evaluating the financial effect of the COVID-19 pandemic is basic for policymakers, yet testing in light of the fact that the emergency has unfurled with outrageous speed. The prime three pointers are - securities exchange unpredictability, newspaper based monetary vulnerability, and abstract vulnerability in business desire reviews - that give ongoing forward-looking vulnerability measures. The COVID-19 pandemic has set off a huge spike in vulnerability. Significant vulnerabilities encompass pretty much every perspective: the irresistibleness, commonness, and lethality of the infection; the accessibility and arrangement of antigen and immune response tests; the limit of medicinal services frameworks to address an unprecedented difficulty; to what extent it will take to create and convey sheltered, compelling antibodies; a definitive size of the mortality stun; the span and viability of social distancing, market lockdowns, and other moderation and control procedures; the close term financial effect of the pandemic and approach reactions; the speed of recuperation as the pandemic retreats; regardless of whether "brief" government intercessions and strategies will continue; the degree to which pandemic-actuated moves in consumer spending 
examples will endure; and the effect on business endurance, new business development, R\&D, human capital venture, and different variables that influence profitability over the medium and long term.

The total market cap lost an amazing $27.31 \%$ from the beginning of the year. The financial market has mirrored the opinions this pandemic released upon investors, foreign and domestic the same. Organizations have downsized; cutbacks have increased and worker compensations have been influenced bringing about irrelevant development over the most recent few months. Certain sector, for example, hospitality, the travel industry and entertainment have been affected unfavorably and stocks of such organizations have dived by over $40 \%$.

Investor activities will in general have the attributes of behavioural inclinations. These behavioural biases lead to mistaken aggregation of securities markets. It happens on account of a psychological framework not founded on the proof yet spurred by inclinations. There are six essential behavioural inclinations: Confirmation bias, Reducing Regret bias, Myopic loss-aversion bias, Limited attention span bias, Chasing Trends bias and Status quo bias. In subjective psychology, one of Popper's inheritances is that confirmation and disconfirmation are frequently rewarded as including distinct procedures; tests are supposed to be either confirming or disconfirming. It is a genuinely typical conclusion in psychology that investors have troubled situation adjusting their perspectives. Investors are said to show an confirmation bias when they consider what is introduced to them.

Reducing Regret bias emerges when speculators dread that their choice will end up being incorrectly looking back. Lament averse investors may fear the outcomes of the two blunders of omission (not accepting the correct offers) and commission (purchasing an inappropriate offers). The longer the investor plans to hold the benefit, the more appealing the risky resource will show up, so long the investment isn't assessed much of the time. The mix of two factors to such an extent that an investor being reluctant to manage the dangers related with holding equities, loss aversion and a short assessment period. The near-sightedness of a loss aversion decision maker can cause an appealing multiperiod investment opportunity to look ugly which is called as Myopic loss aversion predisposition. It is further intriguing for financial applications that examine distinguished numerous approaches to control the level of near-sightedness and in this manner the assessment of venture openings. (Thaler et al.) utilized the input recurrence of past venture results to control the level of near-sightedness.

Due to certain limitations, investors tend to consider only stocks that come to their attention through websites, financial media, friends and family, or other sources outside of their own research instead of making the most efficient decision, they'll make the most satisfactory decision. Investors who chase returns buy assets after they have risen and sell assets after they have fallen. Trend-chasing is based on a single asset such as a stock or across assets as in momentum strategies where one buys recent winners and shorts recent losers. Indeed, one alternative inevitably carries the label status quothat is, doing nothing or maintaining one's current or previous decision is almost always a possibility. Faced with new options, investors often stick with the status quo alternative, for example, to follow customary company policy, to elect an incumbent to still another term in office, to purchase the same product brands, or to stay in the same job.

This paper investigates whether the diverse mental and individual qualities bring about contrasts in speculation conduct and trading performance between investors with various profiles. The article is organized as follows: 
Firstly, the paper tends to chosen behavioural predispositions required among stock market investors and besides it recognizes the related Finance Risk Tolerance elements and COVID-19 factors. A synopsis of the nature of procedure is then clarified, lastly, the discoveries of the investigation are presented.

\section{IMPORTANCE OF RESEARCH}

Prior, Indian economy was essentially encountering a demand log jam while now both demand and supply have been upset. There are four channels through which the effect will get transmitted to yield development. These are: outside supply and demand limitations because of global recession and disturbance of worldwide supply chains, domestic supply interruptions, and decrease in domestic demand. The monetary shock will have sway on both formal and informal divisions.

The equity market has been hitting new lows each day since the outbreak of Covid-19. In March 2020, panic selling because of the pandemic shaved off $23 \%$ market capitalisation of organizations recorded on the National Stock Exchange (NSE) inside a range of only a solitary month. The BSE S\&P Sensex acted comparatively, losing $23 \%$ of its incentive during March 2020. In spite of the fact that the auction was seen in all cases, it was progressively serious for ventures that are hit the hardest by the Covid19 pandemic and the ensuing lockdown, for example, the travel industry, real estate, resource financing administrations, banks, metals industry, vehicle and ancillaries, textiles, power, mining and food item organizations.

Thusly, whether or not it is a triumph or inability to get to the level of risk that investors wish to acknowledge and confirm that combination of advantages fulfills their risk desires. A productive securities market investor is one who tries to achieve in any event pace of return steady with expected risk through
Knowledge of Securities market industry. Along these lines, the liquidity highlight of this market is the most critical perspective which individuals consider before going into stock exchange. It is without a doubt beneficial for speculators to secure behavioural predispositions which has an impact because of the Covid-19 pandemic and the related financial risk resilience capacity that legitimize their responses for better returns.

\section{PROBLEM STATEMENT}

The problem statement is to be would in general right currently "Sharing the Economic Torment due to Covid-19 and relevant Behavioral Biases on Financial Risk Resilience Ability of Securities Market Investors " context of writing is significantly seen under uncertain conditions, and it is the progressing when inclinations come vigorously. The current assessment thinks about six conduct determinants (Confirmation Bias, Reducing Regret Bias, Myopic loss-aversion bias, Limited attention span bias, Chasing Trends bias and Status quo bias) to explore their effect on Financial Risk Resilience ability factors.

The current examination attempts to address the unexplored zone of Central India, where the impact of social factors on Financial Risk Tolerance Ability may be astonishingly higher than the developed countries. The researchers right currently are of the view that behavioural inclinations get individuals more in collectivistic societies because of social effect in choosing investment decisions. Particularly India as a collectivistic culture, the impact of behavioural inclinations should be more in affecting the dynamism of securities market investor.

\section{OBJECTIVES OF THE STUDY}

This research is designed to address the following objectives: 
1. To investigate the connection between the behavioural predispositions and its impact concerning Covid-19 variables.

2. To analyse the relationship between the partialities of securities market investors with regard to Covid-19 pandemic and its effect on Financial risk resilience ability.

3. To consider the dependence between the behavioural biases and Financial risk resilience factors.

\section{HYPOTHESIS FOR THE STUDY}

The hypothesis for this research with respect to the objectives framed is stated as follows:

$\mathrm{H}_{01}$ : There is no relationship between the behavioural biases and Covid-19 variables.

$\mathrm{H}_{02}$ : There is no significant difference among Covid-19 factors and Financial Risk Resilience variables.

$\mathrm{H}_{03}$ : There is no substantial impact between behavioural biases and Financial Risk Resilience factors.

\section{BEHAVIOURAL BIASES IN MAKING INVESTMENT DECISIONS ON SECURITIES MARKET}

Behavioural finance considers the psychological part of money related dynamics and clarifies the madness of investors in investment decision-making. Ordinarily, the investor's conduct veers off from settling on sane or consistent choices and inclines towards being affected by different social predispositions. These predispositions impact the investors reasonability in decision-making. Huckle (2004) remarks that most investor's inclinations are conflicting. The investors capacity to think sanely is undermined further when his/her example looking for characteristics join with misfortune abhorrence to fortify the desire to shy from low costs - despite the fact that exploration demonstrates that asset classes and classifications move in cycles. An essential necessity for gainful investment is to purchase low and sell high as stock market travel through these cycles.

In spite of the fact that the field of Economics has propounded numerous hypotheses throughout the years on human conduct, it has not had the option to clarify why individuals routinely settle on budgetary choices that are unreasonable. There have been studies in the field of finance that clarify and demonstrate the manner in which budgetary markets work, there are likewise examines that causes us to comprehend the elements behind investments whereupon numerous standards have been defined. Despite the fact that these principles on investments are basic, most financial specialists experience difficulty reliably applying them. This prompts most investors either exchanging excessively, purchase and sell at definitely an inappropriate occasion, permit feelings to overrule rationale, misconceive probabilities, or needlessly pursue execution.

Following are a portion of the critical behavioural biases that a securities market investor, intentionally or unconsciously performs while settling on a investment choice:

\section{Confirmation Bias}

Bias alludes to a propensity or tendency. (For instance, in signal recognition hypothesis, a bias is basically a general inclination to support one reaction over another.) Bias can likewise refer to a methodically imperfect judgment process that is eventually malicious to the interests of the investor. As an augmentation of presumptuousness, individuals will in general consider positive outcomes to be as confirmative than a prior choice which was adequately onesided. At the point when a good result happens, they are less inclined to rethink the fundamental purposes behind that result and the likelihood that gains will be rehashed.

Klayman and $\mathrm{Ha}$ (1987) contend that numerous practices thought to reflect confirmation predisposition are better understood as mirroring a 
general "positive tests technique" as per which one tests those examples that are relied upon to fit the estimated rule instead of those expected not to fit. In any case, in an elegant arrangement of contentions, Klayman and Ha exhibited that even the one-sided positive test technique doesn't generally yield confirmatory outcomes. In particular, they exhibit that when one is exploring a generally uncommon marvel, at that point the positive test methodology is probably going to find bogus positives, that is, occasions that, indeed, don't adjust to the standard and that in this way adulterate the theory.

\section{Reducing Regret Bias}

Regret is the second most named feeling, after adoration (Shimanoff,1984) and dissatisfaction is the third most experienced feeling, after anxiety and outrage (Schimmack and Diener, 1997). Past examination has discovered that regret and disillusionment are unmistakably various feelings, with discernable ramifications for decision-making (Martinez, Zeelenberg, and Rijsman, 2008; Zeelenberg, Van Dijk, Manstead, and Van der Pligt, 2000). Along these lines, we anticipate that after a regret induction, selling costs will diminish (individuals will need to remunerate others by selling their assets at a lower cost) and purchasing costs will expand (individuals will purchase at a more significant price so as to change their circumstances) in securities market.

Recent neuropsychological exploration and neuroimaging information have focused on both the significance of foreseen regret as a ground-breaking indicator of future choices (Coricelli et al., 2005), just as the existence of learning dependent on total enthusiastic experiences (Coricelli, Dolan, and Sirigu, 2007) in stock market investments. Since every feeling has a particular phenomenology and explicit social propensities related with it, we anticipate differential impacts for regret and disillusionment.
If we somehow happened to discover support for our forecasts in securities market, the impacts can't be clarified by negative temperament, on the grounds that both regret and frustration will initiate negative state of mind

\section{Myopic Loss-aversion Bias}

Investors are more influenced by recent short-term fluctuations in the value of their investments than by the long-term implications. In light of individual decision-making bulk of the assets we are worried about are held by organisations in securities market. As we worried over, the key segments of our clarification are loss aversion and successive evaluations. Loss abhorrence alludes to the propensity for investors to be progressively delicate to decreases in their degrees of prosperity than to increments. The idea assumes a focal job in Kahneman and Tversky's [1979] expressive hypothesis of decision-making under vulnerability.

Myopic Loss Aversion, proposed by Benartzi and Thaler places that economic operators are loath to misfortunes at a nonsensically short skyline because of institutional reasons or on the grounds that they are influenced by a social inclination (specifically, on the grounds that they are too on edge to even think about evaluating the performance of their portfolio on a transient premise). Benartzi and Thaler demonstrated that the observed equity premium is reliable with a moderate level of loss aversion at a investment skyline of around 1 year, which they see as instinctively sensible. Under loss aversion, investors have a fixed reference point against which they assess gains and misfortunes.

\section{Limited Attention Span Bias}

There are a huge number of stocks to look over however the individual speculator has neither the time nor the craving to investigate each. People are compelled by what financial specialist 
and psychologist Herbert Simon called, "bounded rationality". This hypothesis expresses that a human will settle on choices dependent on the constrained information they can gather. Rather than settling on the most productive choice, they'll settle on the most palatable choice.

As a result of these constraints, investors will in general consider just stocks that become obvious through sites, money related media, loved ones, or different sources outside of their own examination. For instance, if a specific telecom industry gains endorsement for a blockbuster plan for customers, the transition to the upside could be amplified on the grounds that the revealed news grabs the attention of investors. Littler news about a similar stock may cause almost no market response since it doesn't arrive at the media.

\section{Chasing Trends Bias}

This is ostensibly the most grounded trading bias. Researchers on behavioural finance found that $39 \%$ of all new cash resolved to purchase new shares went into the $10 \%$ of offers with the best performance the earlier year. Albeit financial products frequently incorporate the disclaimer that "past execution isn't characteristic of future outcomes," retail traders despite everything accept they can foresee the future by contemplating the past.

Humans have a phenomenal ability for identifying designs and when they discover them, they have faith in their legitimacy. At the point when they discover a pattern, they follow up on it however frequently that pattern is as of now valued in. Regardless of whether an example is discovered, the market is unmistakably more irregular than most traders care to concede. The University of California study found that investors who weighted their choices on past execution were regularly the least fortunate performing when contrasted with others.

\section{Status Quo Bias}

At the point when a decision maker picks between choices, it is regularly the situation that one will be "status quo" or default option. This is the elective that the decision maker will wind up with on the off chance that they don't effectively change to another. The first is that status quo bias as usual inclination is the propensity to pick the norm elective which is increasingly common in bigger decision sets (Samuelson and Zeckhauser, 1988; Redelmeier and Shafir, 1995 and Kempf and Ruenzi, 2006). This presumption normally creates the forecast that Status quo bias will be progressively pervasive in bigger decision sets in which consideration is moderately scanter.

The Status quo bias is characterized as the propensity to choose a formerly picked elective excessively often. Humans frequently acknowledge status quo as usual when confronted with clashing decision choices. Be that as it may, it is obscure how neural pathways associating discernment with action regulate this status quo option. Conduct proof recommends the feeling of disappointment is higher when mistakes emerge from dismissal instead of acceptance of a status quo option. Such asymmetry in the beginning of disappointment may drive status quo bias on resulting choices.

\section{IMPACT OF COVID-19 FACTORS ON SECURITIES MARKET INVESTORS}

Novel Corona Virus Disease (COVID-19) which originated from China has quickly crossed fringes, tainting individuals all through the entire world. This marvel has prompted a monstrous public response; the media has been detailing persistently across fringes to keep all educated about the pandemic circumstance. Every one of these things are making a great deal of worry for individuals prompting elevated degrees of tension. Pandemics can prompt uplifted degrees of stress; Anxiety is a typical reaction to any upsetting circumstance. Investors across the globe are 
monitoring the situations with respect to their investments in securities market. The ongoing downturn in the markets has stressed the way that investments in equity ought not be focused on momentary gains as an essential procedure, but instead at development in value over the longer run. Here are five factors that may affect the behaviour of investors in stepping towards investment:

\section{Rise in Coronavirus Infection in India}

India is recording a huge bounce in coronavirus infections step by step. India has the world's fourth most noteworthy number of Covid19 infections and is simply behind the United States, Brazil and Russia. The dread and nervousness identified with epidemics and pandemics likewise impact the conduct of individuals in the network. The expansion in Covid-19 cases with the numbers approaching 4.5 lakhs and the deaths approaching 15,000 is challenging in the current situation considering the danger of the spread of Covid-19 contamination.

\section{Second Wave of Covid-19 Infections across the Globe}

Nations such as China, South Korea and Iran are wrestling with a second wave of the dangerous coronavirus diseases. This is fuelling fears that the virus is digging in for the long haul. China's subsequent flare-up is focused in the capital Beijing, with at any rate 184 new cases detailed since the second week of June, as authorities restricted outbound travel and forced a fractional lockdown. In view of nervousness, individuals embrace different undesirable way of life and dietary alterations affected by bits of rumours. These may influence emotional wellness antagonistically. Subsequently, investors are not able to cope with and feeling emotionally depleted.

\section{Last Leg of Q4 results}

Top Performing Companies in Securities market such as Asian Paints, Ashok Leyland, Bank of Baroda, Berger Paints, GAIL India, India Cements and Indian Oil Corporation etc. are scheduled to announce their March quarter earnings in the month of June 2020. These companies' earnings have a deep impact on the behaviour of securities market investors. It may also see volatile moves led by strong gains in the market which is an added advantage.

\section{Domestic Data}

Foreign exchange reserves are characterized as outer supply of assets, which is accessible to the nation's monetary authorities to cover external payment imbalances or to impact the conversion scale of the domestic currency through mediation in exchange market, or for different purposes (IMF, 2000). A nation's reserves comprise of gold, outside monetary standards, special drawing rights (SDR) and the reserve position with the International Monetary Fund (IMF). The investors will keep a nearby watch on the information of foreign exchange reserves, scheduled to be released soon. Foreign exchange reserves in the nation rose to $\$ 501.70$ billion on June 5 from $\$ 493.48$ billion in the prior week.

\section{Global Macroeconomic Data}

The distinctive highlights of Macroeconomic information incorporate explicit acknowledgment of the demand and supply interlinkages among agriculture and the remainder of the domestic economy inside a completely endogenous structure for portraying price arrangement; flexible functional forms in depicting economic activity; and unequivocal displaying of fiscal position of the public sector with collected past domestic debt to describe the massive fiscal debt rescheduling challenge of the current Indian economy. On the worldwide front, 
investors will be peering toward full scale macroeconomic reports from world's biggest economy like United States followed by Manufacturing rate, GDP growth rate, Goods Trade balance, Unemployment rate and, FED test results for huge banks which is expected to be discharged soon.

\section{FINANCIAL RISK RESILIENCE OF SECURITIES MARKET INVESTORS:}

Securities exchange market crash far and wide during the pandemic time of Covid-19 exhibited the financial contagion of recent worldwide financial crisis. Despite the financial crisis right off the bat hit securities exchanges in the United States and other developed market, it before long spread far and wide to hit financial exchanges in developing nation like India and other Southeast Asian nations. This is very much clarified as one of the remarkable highlights of globalisations and the quick transmission of information across market is the spread of financial crisis starting with one nation then onto the next, in any event, while hidden economic essentials are extraordinary (Ahlgren and Antell, 2009). Thus, high financial connected between developing business sector and emerging market just turns into the conductor of the contagion. With such market's condition, investors need a manual for making compelling investment portfolio, an investment that can stand market shocks and least risky. Risk is significant in investment since chance is a factor that shapes investors choice to make venture (Lipe, 1998; Yang and Qiu, 2005). Realizing the investment hazard, it guides investor in creating viable investment portfolio particularly during the pandemic time frame.

The capacity to oversee emerging risks, foresee the interactions between various sorts of risk, and ricochet once again from interruption will be a competitive differentiator for investors and nations alike in the 21 st century. The Policymakers should know that national goal isn't to be simply homeland protection, but monetary flexibility: the ability to moderate and recuperate rapidly from interruption. Investors must pull the case for investment in versatility strategies to deal with a range of risks, not simply disastrous ones. Presenting a business defence for investment in safeguards against low-likelihood occasions (even those with high impact) is troublesome. The investment and contingency courses of action investors in securities market make to deal with a spectrum of risk create a capacity to react to highaffect fiascos also. There are a limitless number of interruption situations, however just a limited number of results. Policies to reinforce risk management abilities would serve both security and competitiveness objectives.

\section{RESEARCH FRAMEWORK}

The framework of the research is the diagrammatic representation of the variables used in the study such as the Independent Variables, Mediating Variable and the Dependent Variable. The details are given in Figure.

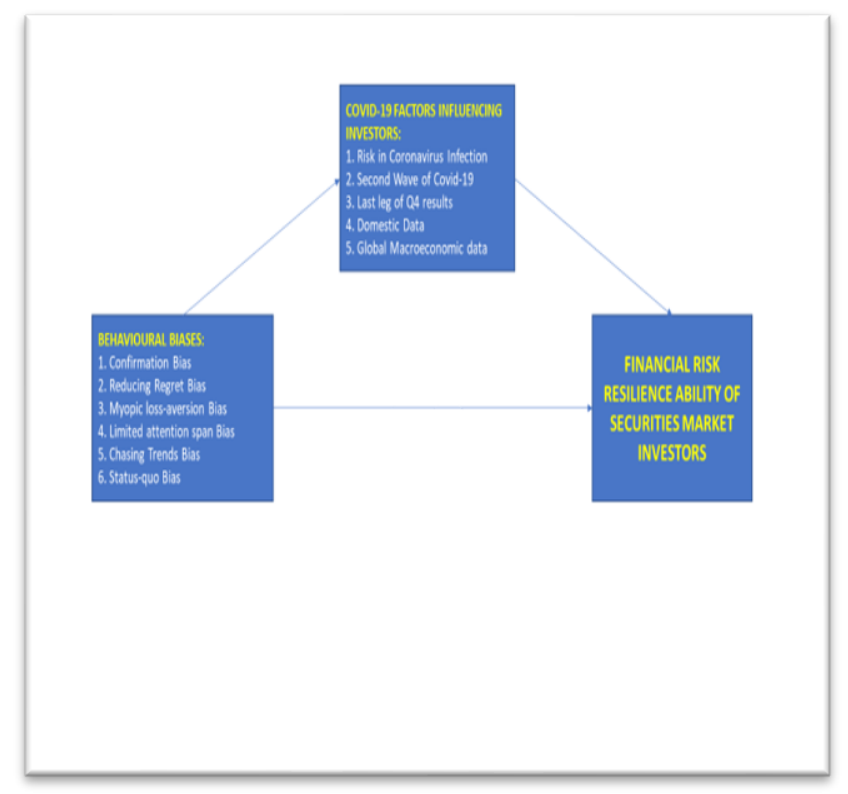

\section{STUDY SAMPLE AND PROCEDURE}

Securities market investors who have a spot with Central India contain the respondents. Since covering the whole population is time taking, Judgment sampling technique was adopted 
to try out the data. The essential drivers of this inspecting method are the capability rate in central India due to which an enormous segment of the speculators doesn't think about the specific terms in stock markets. The review was appropriated to 150 individual investors from March 2020 to June 2020 in the different urban territories of central India.

\section{DATA ANALYSIS \\ Reliability}

Ensuring that the testing instrument is precise is critical to the approval of the information. To direct the full overview, analysts at first played out the pilot testing to guarantee the instrument's unwavering reliability and afterward led a complete examination dependent on the aftereffects of the reliability testing. It is basically a degree to which an evaluation strategy produces steady and predictable outcomes, indicating that the instruments yield similar outcomes if the tests are replicated again and again. For a total overview of 34 questionnaires, the reliability values supplemented our earlier findings, Cronbach's alpha value reaches from 0.821 to 0.913, which shows the strong unwavering quality of the data, which is adequate and thought great. The outcomes referenced underneath likewise supplement the findings.

Table 1: Reliability Statistics

\begin{tabular}{lcr} 
Measurements & \multicolumn{1}{c}{$\begin{array}{c}\text { Number } \\
\text { of Items }\end{array}$} & Reliability \\
$\begin{array}{l}\text { Independent } \\
\text { Variables }\end{array}$ & & \\
\cline { 2 - 3 } $\begin{array}{l}\text { Confirmation Bias } \\
\text { Reducing Regret }\end{array}$ & 4 & 0.904 \\
$\begin{array}{l}\text { Bias } \\
\text { Myopic Loss- }\end{array}$ & 4 & 0.862 \\
$\begin{array}{l}\text { aversion Bias } \\
\text { Limited attention } \\
\text { span Bias }\end{array}$ & 4 & 0.859 \\
$\begin{array}{l}\text { Chasing Trends } \\
\text { Bias }\end{array}$ & 4 & 0.894 \\
$\begin{array}{l}\text { Status quo Bias } \\
\text { Mediating }\end{array}$ & 4 & 0.821 \\
Variable & 4 & 0.83 \\
Covid-19 factors & 4 & \\
influencing & 4 & \\
\cline { 2 - 3 } & & \\
\end{tabular}

www.psychologyandeducation.net

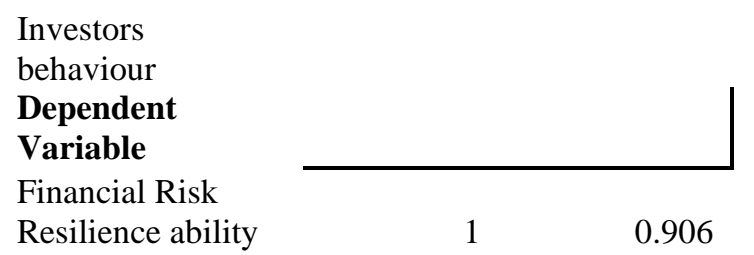

The legitimacy of the questionnaire was estimated utilizing the Content legitimacy index. Reliability is estimated by utilizing Cronbach's alpha coefficient (Santos, 1999). In Statistics, the test utilizing Cronbach alpha ought to be higher than 0.7 , to get the ideal dependability of the survey. From the table 2, it is obvious that the alpha estimation of Confirmation Bias for four items is 0.904, Reducing Regret Bias for four items is 0.862 , Myopic loss aversion bias for four items is 0.859 , Limited attention span bias for four items is 0.894, Chasing Trends Bias for four items is 0.821 and Status quo bias is 0.830 . Dependent variable Financial Risk Resilience for five items has an alpha estimation of 0.906 and Covid-19 impact factors for five items has an estimation of 0.913 which is nearer to 1.0 that implies the dependability of the questionnaire is best for the investigation.

\section{DEMOGRAPHIC PROFILE}

The details about the Demographic Profile is discussed in below Table:

Table 2: Demographic Profile of Securities Market Investors

\begin{tabular}{|c|c|c|c|}
\hline \multirow{2}{*}{$\begin{array}{l}\text { Demographic } \\
\text { Profile }\end{array}$} & \multirow[b]{2}{*}{ Type } & \multicolumn{2}{|c|}{ Frequency } \\
\hline & & Number & Percentage \\
\hline Age Group & $\begin{array}{l}\text { Less than } \\
20 \\
\text { From } 21- \\
35 \\
\text { From } 36- \\
50 \\
51 \text { and } \\
\text { Above }\end{array}$ & 41 & $\begin{array}{l}16.00 \% \\
22.00 \% \\
27.30 \%\end{array}$ \\
\hline \multirow[b]{2}{*}{ Gender } & Male & 100 & $66.70 \%$ \\
\hline & Female & 50 & $33.30 \%$ \\
\hline & Bachelors & 53 & $35.30 \%$ \\
\hline & Masters & 56 & $37.30 \%$ \\
\hline Qualification & Professional & 41 & $27.30 \%$ \\
\hline
\end{tabular}




\begin{tabular}{|c|c|c|c|c|c|c|c|c|}
\hline \multirow{2}{*}{$\begin{array}{l}\text { Duration of } \\
\text { Investment } \\
\text { in Securities } \\
\text { Market }\end{array}$} & \multirow{2}{*}{$\begin{array}{l}\text { Less than } 5 \\
\text { years } \\
\text { Between } 5- \\
10 \text { years } \\
\text { From } 11 \text { - } \\
15 \text { years } \\
16 \text { years } \\
\text { and Above } \\
\text { Up to }\end{array}$} & 41 & $\begin{array}{l}28.70 \% \\
27.30 \%\end{array}$ & \multicolumn{5}{|c|}{$\begin{array}{l}\text { DESCRIPTIVE STATISTICS: } \\
\text { The Information about the Descriptive statistics } \\
\text { are given in below table: } \\
\text { Table: Descriptive Statistics }\end{array}$} \\
\hline & & 37 & $24.70 \%$ & Measurements & Mean & $\begin{array}{l}\text { Standard } \\
\text { Deviation }\end{array}$ & Skewness & $\begin{array}{r}\text { Kurtosi } \\
\mathbf{s} \\
\end{array}$ \\
\hline \multirow[b]{2}{*}{$\begin{array}{l}\text { Monthly } \\
\text { Income }\end{array}$} & $\begin{array}{l}\text { Up to } \\
40,000\end{array}$ & 40 & $26.70 \%$ & $\begin{array}{l}\text { Confirmation } \\
\text { Bias }\end{array}$ & & & & \\
\hline & $\begin{array}{l}40,001- \\
70,000 \\
70,001- \\
1,00,000 \\
\text { More than } \\
1,00,000\end{array}$ & 39 & $24.00 \%$ & \begin{tabular}{|l|} 
Confirmation \\
biases impact how \\
we gather \\
information, but \\
they also influence
\end{tabular} & 3.19 & 1.389 & -0.230 & -1.329 \\
\hline \multirow[b]{2}{*}{$\begin{array}{l}\text { Amount } \\
\text { Invested in } \\
\text { Securities } \\
\text { Market } \\
\end{array}$} & $\begin{array}{l}\text { Below } \\
25,000 \\
25,001- \\
\mathbf{5 0 , 0 0 0}\end{array}$ & 35 & $23.30 \%$ & $\begin{array}{l}\text { how we interpret } \\
\text { and recall } \\
\text { information. }\end{array}$ & & & & \\
\hline & $\begin{array}{l}50,001- \\
1,00,000 \\
\text { Above } \\
1,00,000\end{array}$ & 41 & $27.30 \%$ & $\begin{array}{l}\text { Investors have } \\
\text { very different } \\
\text { opinions on the }\end{array}$ & 3.24 & 1.473 & -0.270 & -1.415 \\
\hline $\begin{array}{l}\text { Annual } \\
\text { Savings }\end{array}$ & $\begin{array}{l}\text { Less than } \\
1,00,000 \\
1,00,000- \\
3,00,000 \\
\text { Above } \\
\text { 3,00,000 }\end{array}$ & 56 & $37.30 \%$ & $\begin{array}{l}\text { same stocks and } \\
\text { their } \\
\text { interpretations are } \\
\text { based on their } \\
\text { beliefs. }\end{array}$ & & & & \\
\hline Occupation & $\begin{array}{l}\text { Student } \\
\text { Private } \\
\text { Sector } \\
\text { Public } \\
\text { Sector } \\
\text { Business }\end{array}$ & $\begin{array}{l}25 \\
36\end{array}$ & $\begin{array}{l}16.70 \% \\
24.00 \%\end{array}$ & $\begin{array}{l}\text { Confirmation bias } \\
\text { can prevent us } \\
\text { from looking at } \\
\text { situations } \\
\text { objectively. It can }\end{array}$ & 3.22 & 1.385 & -0.234 & -1.302 \\
\hline \multirow[b]{2}{*}{$\begin{array}{l}\text { Invested } \\
\text { Savings } \\
\text { Percentage }\end{array}$} & $\begin{array}{l}\text { Less than } \\
10 \% \\
\text { Between } 10 \\
\%-20 \%\end{array}$ & 29 & $19.30 \%$ & $\begin{array}{l}\text { decisions we make } \\
\text { and lead to poor or } \\
\text { faulty choices. }\end{array}$ & & & & \\
\hline & $\begin{array}{l}21 \%-30 \\
\% \\
\text { More than } \\
30 \%\end{array}$ & 39 & $26.00 \%$ & $\begin{array}{l}\text { Confirmation bias } \\
\text { does exist and we } \\
\text { can make an effort }\end{array}$ & 3.41 & 1.316 & -0.465 & -1.022 \\
\hline \multirow[t]{2}{*}{$\begin{array}{l}\text { Mode of } \\
\text { Buying } \\
\text { Shares } \\
\end{array}$} & $\begin{array}{l}\text { Private } \\
\text { Placement } \\
\text { Through } \\
\text { Brokerages } \\
\text { Banks } \\
\text { Individual } \\
\text { Investors }\end{array}$ & $\begin{array}{l}47 \\
38\end{array}$ & $\begin{array}{l}31.30 \% \\
25.30 \%\end{array}$ & $\begin{array}{l}\text { working to be } \\
\text { curious about } \\
\text { opposing views } \\
\text { and really listening } \\
\text { to what others } \\
\text { have to say and } \\
\text { why. }\end{array}$ & & & & \\
\hline & & & & $\begin{array}{l}\text { Reducing Regret } \\
\text { Bias }\end{array}$ & & & & \\
\hline
\end{tabular}




\begin{tabular}{|c|c|c|c|c|}
\hline $\begin{array}{l}\text { Regret Aversion in } \\
\text { basic words is the } \\
\text { pattern to abstain } \\
\text { from settling on } \\
\text { choice because of } \\
\text { the dread of } \\
\text { suffering the hurt } \\
\text { of regrets. }\end{array}$ & 3.67 & 1.196 & -0.752 & -0.436 \\
\hline $\begin{array}{l}\text { Regret bias looks } \\
\text { to figure the } \\
\text { discomfort of } \\
\text { regret associated } \\
\text { with poor } \\
\text { investment choice } \\
\text { making. }\end{array}$ & 3.42 & 1.206 & -0.602 & -0.542 \\
\hline $\begin{array}{l}\text { Specifically, regret } \\
\text { bias assesses how } \\
\text { regret aversion } \\
\text { impacts choice } \\
\text { making process, } \\
\text { choice, and post- } \\
\text { decisional } \\
\text { practices among } \\
\text { investors. }\end{array}$ & 3.62 & 1.191 & -0.628 & -0.387 \\
\hline \begin{tabular}{|l|} 
Regret is seen as \\
an imperious \\
negative feeling \\
among investors.
\end{tabular} & 3.50 & 1.294 & -0.414 & -0.940 \\
\hline \multicolumn{5}{|l|}{\begin{tabular}{|l} 
Myopic Loss \\
Aversion Bias \\
\end{tabular}} \\
\hline $\begin{array}{l}\text { Myopic loss } \\
\text { aversion occurs } \\
\text { when investors } \\
\text { take a view of } \\
\text { their investments } \\
\text { that is strongly } \\
\text { focused on the } \\
\text { short term. }\end{array}$ & 3.56 & 1.201 & -0.791 & -0.422 \\
\hline $\begin{array}{l}\text { Myopic loss } \\
\text { aversion is } \\
\text { influenced by } \\
\text { narrow framing, } \\
\text { which is the result } \\
\text { of investors } \\
\text { considering } \\
\text { specific } \\
\text { investments. }\end{array}$ & 3.29 & 1.324 & -0.257 & -1.230 \\
\hline
\end{tabular}

\begin{tabular}{|c|c|c|c|c|}
\hline $\begin{array}{l}\text { In Myopic loss } \\
\text { aversion } \\
\text { individuals who } \\
\text { receive } \\
\text { information about } \\
\text { investment } \\
\text { performance too } \\
\text { frequently tend to } \\
\text { underinvest in } \\
\text { riskier assets, } \\
\text { losing out on the } \\
\text { potential for better } \\
\text { long-term gains. }\end{array}$ & 3.25 & 1.312 & -0.263 & -1.213 \\
\hline $\begin{array}{l}\text { Myopic loss } \\
\text { aversion is the } \\
\text { combination of a } \\
\text { greater sensitivity } \\
\text { to losses than to } \\
\text { gains and a } \\
\text { tendency to } \\
\text { evaluate outcomes } \\
\text { frequently. }\end{array}$ & 3.45 & 1.378 & -0.472 & -1.147 \\
\hline $\begin{array}{l}\text { Limited Attention } \\
\text { Span Bias }\end{array}$ & & & & \\
\hline $\begin{array}{l}\text { There are } \\
\text { thousands of } \\
\text { stocks to choose } \\
\text { from but the } \\
\text { individual investor } \\
\text { has neither the } \\
\text { time nor the desire } \\
\text { to research each. }\end{array}$ & 3.13 & 1.359 & -0.050 & -1.354 \\
\hline \begin{tabular}{|l|} 
Humans are \\
constrained by \\
what economist \\
and psychologist \\
called, bounded \\
rationality. This is \\
limited attention \\
span bias.
\end{tabular} & 3.17 & 1.483 & -0.140 & -1.506 \\
\hline $\begin{array}{l}\text { Limited attention } \\
\text { states that a human } \\
\text { will make } \\
\text { decisions based on } \\
\text { the limited } \\
\text { knowledge they } \\
\text { can accumulate. }\end{array}$ & 3.27 & 1.384 & -0.183 & -1.352 \\
\hline
\end{tabular}


Article Received: 16th October, 2020; Article Revised: 30th December, 2020; Article Accepted: 08th January, 2021

\begin{tabular}{|c|c|c|c|c|}
\hline $\begin{array}{l}\text { Because of certain } \\
\text { limitations, } \\
\text { investors tend to } \\
\text { consider only } \\
\text { stocks that come to } \\
\text { their attention } \\
\text { through websites, } \\
\text { financial media, } \\
\text { friends and family, } \\
\text { or other sources } \\
\text { outside of their } \\
\text { own research. }\end{array}$ & 3.75 & 1.227 & -0.873 & -0.243 \\
\hline \multicolumn{5}{|l|}{\begin{tabular}{|l|} 
Chasing Trends \\
Bias
\end{tabular}} \\
\hline $\begin{array}{l}\text { Although financial } \\
\text { products often } \\
\text { include the } \\
\text { disclaimer that } \\
\text { "past performance } \\
\text { is not indicative of } \\
\text { future results," } \\
\text { investors still } \\
\text { believe they can } \\
\text { predict the future } \\
\text { by studying the } \\
\text { past. }\end{array}$ & 3.09 & 1.447 & -0.086 & -1.434 \\
\hline $\begin{array}{l}\text { Investors have an } \\
\text { extraordinary } \\
\text { talent for detecting } \\
\text { patterns and when } \\
\text { they find them, } \\
\text { they believe in } \\
\text { their validity. }\end{array}$ & 3.29 & 1.368 & -0.181 & -1.354 \\
\hline $\begin{array}{l}\text { Even if a pattern is } \\
\text { found, the market } \\
\text { is far more random } \\
\text { than most traders } \\
\text { care to admit. }\end{array}$ & 3.99 & 1.129 & -1.363 & 1.350 \\
\hline \begin{tabular}{|l|} 
Investors who \\
weighted their \\
decisions on past \\
performance were \\
often the poorest \\
performing when \\
compared to other \\
investors.
\end{tabular} & 3.47 & 1.344 & -0.583 & -0.940 \\
\hline
\end{tabular}

\begin{tabular}{|c|c|c|c|c|}
\hline $\begin{array}{l}\text { Status quo Bias } \\
\text { provide } \\
\text { experimental } \\
\text { evidence for the } \\
\text { existence of status- } \\
\text { quo bias in several } \\
\text { decision-making } \\
\text { contexts and } \\
\text { situations. }\end{array}$ & 3.69 & 1.050 & -0.787 & -0.182 \\
\hline $\begin{array}{l}\text { Uncertainty in the } \\
\text { decision's } \\
\text { situation, which } \\
\text { requires costly } \\
\text { effort to } \\
\text { investigate } \\
\text { alternatives and } \\
\text { their benefits is } \\
\text { seen in status quo } \\
\text { bias. } \\
\end{array}$ & 3.75 & 1.165 & -0.781 & -0.254 \\
\hline $\begin{array}{l}\text { Status-quo bias is } \\
\text { not a mistake-like } \\
\text { a calculation error } \\
\text { or an error in } \\
\text { maximizing but a } \\
\text { true behavioral } \\
\text { bias that is in line } \\
\text { with loss aversion, } \\
\text { but not solely } \\
\text { triggered by it. }\end{array}$ & 3.76 & 1.145 & -0.957 & 0.325 \\
\hline $\begin{array}{l}\text { The status-quo } \\
\text { bias is most often } \\
\text { related to the } \\
\text { concept of } \\
\text { endowment effect } \\
\text { i.e. the differences } \\
\text { in buying and } \\
\text { selling prices in } \\
\text { various market } \\
\text { situations. }\end{array}$ & 3.46 & 1.230 & -0.390 & -0.994 \\
\hline \begin{tabular}{|l|} 
COVID-19 \\
Factors \\
\end{tabular} & & & & \\
\hline $\begin{array}{l}\text { Risk in } \\
\text { Coronavirus } \\
\text { Infection }\end{array}$ & 3.76 & 1.185 & -0.969 & 0.086 \\
\hline $\begin{array}{l}\text { Second wave of } \\
\text { Covid-19 }\end{array}$ & 3.86 & 1.226 & -0.902 & -0.232 \\
\hline Last leg of Q4 & 3.76 & 1.127 & -0.881 & 0.062 \\
\hline
\end{tabular}




\begin{tabular}{|l|r|r|r|r|}
\hline results & & & & \\
\hline Domestic Data & 3.78 & 1.016 & -0.908 & 0.593 \\
\hline $\begin{array}{l}\text { Global } \\
\text { Macroeconomic } \\
\text { Data }\end{array}$ & 3.56 & 1.298 & -0.591 & -0.794 \\
\hline $\begin{array}{l}\text { Financial Risk } \\
\text { Resilience Ability }\end{array}$ & 3.90 & 1.174 & -1.164 & 0.596 \\
\hline
\end{tabular}

The descriptive analysis observes the trend of the data. The table shows the Mean values, Standard deviation, Skewness and Kurtosis. The values of skewness must be between the acceptable range, i.e. from -1 to +1 and values of kurtosis should range from +3 to -3 . If the data lies outside the stipulated range, it means the data is abnormal. The score of Mean and Standard deviation for "Confirmation Bias" is 3.265 and 1.390 with four questions selected for analysis. The score of Mean and Standard deviation for "Reducing Regret Bias" is 3.552 and 1.221 with four questions chosen for analysis. The score of Mean and Standard deviation for "Myopic loss aversion Bias" is 3.387 and 1.303 with four questions selected for analysis. The score of Mean and Standard deviation for "Limited attention span Bias" is 3.330 and 1.363 with four questions chosen for analysis. The score of Mean and Standard deviation for "Chasing Trends Bias" is 3.460 and 1.322 with four questions selected for analysis. The score of Mean and Standard deviation for "Status quo Bias" is 3.665 and 1.147 with four chosen questions for analysis. Concerning dependent variables, the score of Mean and Standard deviation for "Financial Risk
Tolerance" is 3.90 and 1.174 with one parameter selected for analysis. The score of Mean and Standard deviation for "Covid-19 factors Influencing Investors" which is the mediating variable is 3.744 and 1.170 with five questions chosen for analysis. It is evident that all the statistics of Mean, Standard deviation, Skewness and kurtosis are within the acceptable range.

\section{CORRELATION ANALYSIS:}

Authoritative correlation examination is a factual strategy utilized to explore association among two or more variable sets, each comprising of at any rate two factors. Standard correlation analysis is the multivariate type of the general linear model, which presumes that all examinations are correlational, determine evaluates by applying loads to estimated variables, and yield variance-accounted-for impact sizes. A definitely more significant kind of intricacy than the sheer assortment of examination factors lies in the impact of relationship among the variables. In this examination, relationship is accomplished for behavioural predispositions and Covid-19 Factors affecting Investors. Relationship lies between - 1 and +1 , with -1 meaning negative correlation and +1 characterizing positive relationship. 0 suggests no relationship among the variables.

$\mathrm{H}_{01}$ : There is no relationship between the behavioural biases and Covid-19 variables.

Table: Correlation Table

\begin{tabular}{|c|c|c|c|c|c|c|c|c|c|c|c|c|}
\hline \multicolumn{13}{|c|}{ Correlations } \\
\hline & & $\begin{array}{c}\text { Confiden } \\
\text { ce bias }\end{array}$ & $\begin{array}{l}\text { Reducin } \\
\text { g regret }\end{array}$ & $\begin{array}{c}\text { Myopic } \\
\text { loss } \\
\text { aversio } \\
n \text { bias }\end{array}$ & $\begin{array}{c}\text { Limited } \\
\text { attentio } \\
\text { n span } \\
\text { bias }\end{array}$ & $\begin{array}{c}\text { Chasin } \\
\mathrm{g} \\
\text { trends } \\
\text { bias }\end{array}$ & \begin{tabular}{|c} 
Status \\
quo \\
bias
\end{tabular} & $\begin{array}{c}\text { Risk in } \\
\text { Coronavir } \\
\text { us } \\
\text { Infection }\end{array}$ & \begin{tabular}{|c} 
Secon \\
d \\
wave \\
of \\
Covid \\
-19
\end{tabular} & $\begin{array}{c}\text { Last } \\
\text { leg of } \\
\text { Q4 } \\
\text { result } \\
\text { s }\end{array}$ & Domestic & $\begin{array}{c}\text { Global } \\
\text { Macroecon } \\
\text { omic Data }\end{array}$ \\
\hline $\begin{array}{l}\text { Confidence } \\
\text { bias }\end{array}$ & $\begin{array}{l}\text { Pearson } \\
\text { Correlati } \\
\text { on }\end{array}$ & W & & & & & & & & & & \\
\hline
\end{tabular}




\begin{tabular}{|c|c|c|c|c|c|c|c|c|c|c|c|c|}
\hline $\begin{array}{l}\text { Reducing } \\
\text { regret bias }\end{array}$ & $\begin{array}{l}\text { Pearson } \\
\text { Correlati } \\
\text { on }\end{array}$ & $0.849^{* * *}$ & 1 & & & & & & & & & \\
\hline $\begin{array}{l}\text { Myopic loss } \\
\text { aversion bias }\end{array}$ & \begin{tabular}{|l} 
Pearson \\
Correlati \\
on
\end{tabular} & $0.842^{\text {*** }}$ & $0.850^{* * *}$ & 1 & & & & & & & & \\
\hline $\begin{array}{l}\text { Limited } \\
\text { attention } \\
\text { span bias }\end{array}$ & $\begin{array}{l}\text { Pearson } \\
\text { Correlati } \\
\text { on }\end{array}$ & $0.877^{\text {*** }}$ & $0.876^{* *}$ & $0.870^{* * *}$ & 1 & & & & & & & \\
\hline $\begin{array}{l}\text { Chasing } \\
\text { trends bias }\end{array}$ & $\begin{array}{l}\text { Pearson } \\
\text { Correlati } \\
\text { on }\end{array}$ & $0.859^{\text {*** }}$ & $0.877^{* *}$ & $0.904^{* * *}$ & $0.910^{\text {*** }}$ & 1 & & & & & & \\
\hline $\begin{array}{l}\text { Status quo } \\
\text { bias }\end{array}$ & $\begin{array}{l}\text { Pearson } \\
\text { Correlati } \\
\text { on }\end{array}$ & $0.715^{\text {** }}$ & $0.824^{* *}$ & $0.802^{* *}$ & $0.764^{\text {*** }}$ & $0.849^{\text {** }}$ & 1 & & & & & \\
\hline \begin{tabular}{|l|} 
Risk in \\
Coronavirus \\
Infection \\
\end{tabular} & \begin{tabular}{|l} 
Pearson \\
Correlati \\
on
\end{tabular} & $0.574^{* * *}$ & $0.611^{\text {** }}$ & $0.531^{\text {*** }}$ & $0.566^{\text {*** }}$ & $0.599^{* * *}$ & $0.553^{\circ}$ & 1 & & & & \\
\hline $\begin{array}{l}\text { Second wave } \\
\text { of Covid-19 }\end{array}$ & $\begin{array}{l}\text { Pearson } \\
\text { Correlati } \\
\text { on }\end{array}$ & $0.580^{\text {*** }}$ & $0.574^{* * *}$ & $0.497^{* *}$ & $0.541^{* * *}$ & $0.549^{\text {*** }}$ & $0.531^{\prime}$ & $0.766^{* * *}$ & 1 & & & \\
\hline $\begin{array}{l}\text { Last leg of } \\
\text { Q4 results }\end{array}$ & \begin{tabular}{|l} 
Pearson \\
Correlati \\
on
\end{tabular} & $0.532^{\text {*** }}$ & $0.566^{* *}$ & $0.480^{\text {*** }}$ & $0.502^{\text {*** }}$ & $0.528^{* * *}$ & $0.535^{\circ}$ & $0.755^{* * *}$ & $0.743^{*}$ & 1 & & \\
\hline $\begin{array}{l}\text { Domestic } \\
\text { Data }\end{array}$ & $\begin{array}{l}\text { Pearson } \\
\text { Correlati } \\
\text { on }\end{array}$ & $0.534^{\text {** }}$ & $0.546^{* *}$ & $0.548^{\text {*** }}$ & $0.517^{* * *}$ & $0.558^{* *}$ & $0.522^{\circ}$ & $0.714^{\text {*** }}$ & $\begin{array}{r}0.740^{*} \\
*\end{array}$ & $0.692^{*}$ & 1 & \\
\hline \begin{tabular}{|l|} 
Global \\
Macroecono \\
mic Data
\end{tabular} & \begin{tabular}{|l} 
Pearson \\
Correlati \\
on
\end{tabular} & $0.553^{\text {*** }}$ & $0.537^{*}$ & $0.512^{*}$ & $0.530^{* *}$ & $0.544^{* * *}$ & $0.513^{3}$ & $0.607^{\text {** }}$ & $0.606^{*}$ & $0.605^{*}$ & $0.639^{* * *}$ & 1 \\
\hline
\end{tabular}

The Correlations among the variables is given in above Table and it is evident that there is a positive linear relationship between Behavioural biases variables and Covid-19 factors influencing Investors. The course of the relationship is positive, in the sense that these variables tend to increase together same as that of other variables also.

\section{ANOVA FOR COVID-19 FACTORS WITH REGARD TO FINANCIAL RISK RESILIENCE:}

The one-way analysis of variance (ANOVA) is used to determine whether there are any statistically significant differences between the means of two or more independent (unrelated) groups. In this case, the five Covid-19 factors influencing investors and Financial Risk Resilience variable.

$\mathrm{H}_{02}$ : There is no significant difference among Covid-19 factors and Financial Risk Resilience variables.

Table : ANOVA - Covid-19 Factors and Financial Risk Resilience.

\begin{tabular}{|l|l|r|r|r|r|r|}
\hline \multicolumn{7}{|c|}{ ANOVA } \\
\hline \multicolumn{2}{|c|}{} & Sum of Squares & df & Mean Square & \multicolumn{1}{c|}{ F } & Sig. \\
\hline $\begin{array}{l}\text { Risk in Coronavirus } \\
\text { Infection }\end{array}$ & Between Groups & 86.444 & 4 & 21.611 & 25.494 & .000 \\
\cline { 2 - 8 } & Within Groups & 122.916 & 145 & .848 & & \\
\hline & Total & 209.360 & 149 & & & \\
\hline
\end{tabular}


Article Received: 16th October, 2020; Article Revised: 30th December, 2020; Article Accepted: 08th January, 2021

\begin{tabular}{|c|c|c|c|c|c|c|}
\hline \multirow[t]{3}{*}{ Second wave of Covid-19 } & Between Groups & 86.857 & 4 & 21.714 & 22.948 & .000 \\
\hline & Within Groups & 137.203 & 145 & .946 & & \\
\hline & Total & 224.060 & 149 & & & \\
\hline \multirow[t]{3}{*}{ Last leg of Q4 results } & Between Groups & 66.940 & 4 & 16.735 & 19.822 & .000 \\
\hline & Within Groups & 122.420 & 145 & .844 & & \\
\hline & Total & 189.360 & 149 & & & \\
\hline \multirow[t]{3}{*}{ Domestic Data } & Between Groups & 54.755 & 4 & 13.689 & 20.052 & .000 \\
\hline & Within Groups & 98.985 & 145 & .683 & & \\
\hline & Total & 153.740 & 149 & & & \\
\hline \multirow[t]{3}{*}{ Global Macroeconomic Data } & Between Groups & 80.237 & 4 & 20.059 & 17.037 & .000 \\
\hline & Within Groups & 170.723 & 145 & 1.177 & & \\
\hline & Total & 250.960 & 149 & & & \\
\hline
\end{tabular}

The above shows there is significant difference in Covid-19 factors with Financial risk Resilience variable by rejecting the null hypothesis since the p-value is less than 0.05 at $95 \%$ Confidence Level.

\section{REGRESSION ANALYSIS:}

Regression analysis is utilized when we need to foresee the estimation of a variable dependent on the estimation of at least two different factors. The variable we need to foresee is known as the dependent variable (or once in a while, the result, target or rule variable). The factors we are utilizing to foresee the estimation of the dependent variable are known as the independent variables (or now and again, the indicator, explanatory or regressor factors). Regression additionally permits to decide the general fit (fluctuation clarified) of the model and the overall commitment of every one of the indicators to the total variance clarified.

Table 12.7.1: Behavioural Biases over Financial Risk Resilience ability

\begin{tabular}{|l|r|r|r|r|}
\hline \multicolumn{7}{|c|}{ Model Summary } \\
\hline Model & R & \multicolumn{1}{|c|}{ R Square } & Adjusted R Square & \multicolumn{2}{|c|}{$\begin{array}{c}\text { Std. Error of the } \\
\text { Estimate }\end{array}$} \\
\hline 1 & $0.447^{\mathrm{a}}$ & 0.200 & 0.166 & 1.087 \\
\hline
\end{tabular}

The Model Summary is described in Table 12.7.1. It provides the $\mathrm{R}$ and $\mathrm{R}^{2}$ values. The $\mathrm{R}$ value represents the simple correlation and is 0.447 (the " $\mathrm{R}$ " Column), which indicates a high degree of correlation. The $\mathrm{R}^{2}$ value (the "R Square" column) indicates how much of the total variation in the dependent variable, Financial Risk Resilience ability can be explained by the independent variable, Investors Behavioural biases. In this scenario $44.7 \%$ can be explained which is good.

www.psychologyandeducation.net
Table 12.7.2: ANOVA

\begin{tabular}{|c|c|c|c|c|c|}
\hline Model & $\begin{array}{c}\text { Sum of } \\
\text { Squares }\end{array}$ & $\begin{array}{l}\text { Degrees of } \\
\text { freedom }\end{array}$ & $\begin{array}{c}\text { Mean } \\
\text { Square }\end{array}$ & F value & Sig. \\
\hline $\begin{array}{l}\text { Regressio } \\
\text { n }\end{array}$ & 44.246 & 6 & 7.041 & \multirow{3}{*}{5.955} & \multirow{3}{*}{$0.000^{\mathrm{b}}$} \\
\hline Residual & 169.087 & 143 & 1.182 & & \\
\hline Total & 211.333 & 149 & & & \\
\hline
\end{tabular}

The Details of ANOVA is given in above table. It indicates that the regression model predicts the dependent variable significantly well. "Sig." column indicates the statistical significance of the regression model that was run. Here, $p<0.0005$, which is less than 0.05 , and indicates that, overall, 
the regression model statistically significantly for the data. predicts the outcome variable i.e., it is a good fit

Table 12.7.3: Coefficients Table

\begin{tabular}{|c|c|c|c|c|c|}
\hline \multirow[b]{2}{*}{ Model } & \multicolumn{2}{|c|}{ Unstandardized Coefficients } & \multirow{2}{*}{$\begin{array}{c}\begin{array}{c}\text { Standardized } \\
\text { Coefficients }\end{array} \\
\text { Beta }\end{array}$} & \multirow[b]{2}{*}{$\mathbf{t}$} & \multirow[b]{2}{*}{ Sig. } \\
\hline & B & Std. Error & & & \\
\hline (Constant) & 3.897 & 0.272 & & 14.303 & 0.000 \\
\hline $\begin{array}{l}\text { Confirmation } \\
\text { Bias }\end{array}$ & -0.011 & 0.121 & -0.012 & -0.088 & 0.930 \\
\hline $\begin{array}{l}\text { Reducing Regret } \\
\text { Bias }\end{array}$ & 0.084 & 0.124 & 0.103 & 0.679 & 0.498 \\
\hline $\begin{array}{l}\text { Myopic loss } \\
\text { Aversion Bias }\end{array}$ & -0.669 & 0.138 & -0.631 & -4.850 & 0.000 \\
\hline $\begin{array}{l}\text { Limited attention } \\
\text { span Bias }\end{array}$ & 0.014 & 0.125 & 0.018 & 0.114 & 0.910 \\
\hline $\begin{array}{l}\text { Chasing Trends } \\
\text { Bias }\end{array}$ & 0.190 & 0.144 & 0.236 & 1.315 & 0.191 \\
\hline Status quo Bias & 0.339 & 0.128 & 0.412 & 2.656 & 0.009 \\
\hline
\end{tabular}

The Details about the Coefficients is discussed in table above which provides us with the necessary information to predict Financial risk Resilience ability from Investors Behavioural Biases on Mutual Funds, as well as determine whether Behavioural biases contributes statistically significantly to the model (by looking at the "Sig." column). Furthermore, we can use the values in the "B" column under the "Unstandardized Coefficients" column, as shown above:

$$
\begin{gathered}
Y=3.897(\text { constant })-0.011\left(X_{01}\right)+0.084 \\
\left(X_{02}\right)-0.669\left(X_{03}\right)+0.014\left(X_{04}\right)+0.190\left(X_{05}\right) \\
+0.339\left(X_{06}\right)
\end{gathered}
$$

\section{RECOMMENDATIONS FOR OVERCOMING BEHAVIOURAL INCLINATIONS}

Individual Investors in the market ought to permit experts to deal with their portfolios; this will decrease individual inclinations in the administration of the portfolio. Professionals in consulting and investment management ought to be presented to the field of behavioural finance through workshops and seminars with the end goal that when choices are been taken, behavioural inclinations will lessen. Capital market analyst and information suppliers in the Indian security market should think about an appropriate method of discharging information about the securities market to the general population as this have a method of influencing the choice taken by the investors about the market. Institutional investors ought as far as possible focus on any one stock or part that can be held by the organization. Aggregate perspectives on an investment ought to be applied by fund managers and investors as this has propensities of decreasing individual inclinations on an investment. Arrangement of committees could be utilized; however, the utilization of advisory groups has its own ramifications.

Black swan is the event of an exceptionally unforeseen occasion that additionally has an extraordinary effect. The field of finance routinely endeavours to catch anomaly occasions and falls flat with equivalent normality. Effect of novel coronavirus (COVID-19) on the securities exchange is one such occasion, which has all attributes of dark swan. It is stupid to 1089 
expect a fast-monetary bounce back from the current COVID-19 impact. Despite the fact that the money related emergency is unavoidable, thinking about full scale endeavours by central banks and fiscal authorities, to mellow the blow, profound monetary slump may be kept away from. The issue in the current situation is that until we know how rapidly and altogether the general wellbeing challenge will be met, financial analysts can't anticipate the endgame of this emergency.

\section{CONCLUSIONS:}

This paper utilizes primary survey data joined with stock market investors information and offers a definite glance at the degree of behavioural inclinations in the Indian security market, just as the outcome of such predispositions on securities exchange execution. The paper has tried certain behavioural predispositions and Covid-19 factors as distinguished by behavioural finance specialists on securities exchange performance: the trading mentality of haphazardly chosen investors the market was tested, utilizing illustrative and parametric insights. The Investors were chosen across discipline and age layers mirroring a cross area of the market participant. The paper reasons that, monitoring behavioural predispositions is the significant initial phase in guaranteeing that the decision-making isn't unfavourably influenced by them. Rational choices are more probable when there is adequate data accessible to decisionmakers and when that data is introduced and broke down to perceive regular traps.

Markets are commonly forward-looking, and apparently a noteworthy segment of the negative impacts of COVID-19, and the economy slowdown, has just been limited. Unexpected news will decide any exceptional market developments at either end. A slowdown in development is inescapable, however indications of recuperation will be instrumental in pushing markets back up. In this market situation, it is hard to anticipate a firm base or top.

With decreasing Interest rate and vulnerability in the real estate sector, financial exchanges are turning into an undeniably rewarding road for capital inflows. While it is a decent chance to enter the market, alert is prompted. Along these lines, it is suggested keeping up sufficient liquidity of in any event $25 \%$ at singular portfolio levels, and to put resources into the market in a stunned, orderly way, without influence, and with enough expansion across segments.

The paper finds evidence that Confirmation, Reducing Regret, Myopic loss Aversion, Limited attention span, Chasing Trends and Status quo biases exists concerning Covid-19 variables in the Indian security markets. The paper presumes that, monitoring behavioural inclinations is the vital initial step and Covid-19 components being secondary in guaranteeing that the dynamic procedure isn't unfavourably influenced by them. Rational choices are almost certain when there is adequate data accessible to decision-makers and when that data is introduced and analysed to perceive regular pitfalls.

\section{REFERENCES:}

1. Fong W.M. (2014) Trend-Chasing. In: The Lottery Mindset: Investors, Gambling and the Stock Market. Palgrave Pivot, London.

2. Covid-Induced Economic Uncertainty: National Bureau of Economic Research - Scott R. Baker, Nicholas Bloom, Steven J. Davis and Stephen J. Terry.

3. The Unprecedented Stock Market Impact of Covid-19: National Bureau of Economic Research - Scott R. Baker, Nicholas Bloom, Steven J. Davis, Kyle J. Kost, Marco C. Sammon and Tasaneeya Viratyosin.

4. Covid-19: Impact on the Indian Economy - S. Mahendra Dev and Rajeswari Sengupta - Indira Gandhi Institute of Development Research (IGIDR) 
5. Investors' Behavioural Biases and the Security Market: An Empirical Study of the Nigerian Security Market Abiola Ayopo Babajide PhD (Corresponding author) Department of Banking and Finance, Covenant University, Nigeria.

6. Myopic loss aversion, disappointment aversion and the equity premium puzzle: David Fielding and Livio Stracca - Department of Economics, University of Otago, Dunedin, New Zealand.

7. Study of knowledge, attitude, anxiety \& perceived mental healthcare need in Indian population during COVID-19 pandemic - Deblina Roy, Sarvodaya Tripathy, Sujita Kumar Kar, Nivedita Sharma, Sudhir Kumar Verma and Vikas Kaushal.

8. Demand for Foreign Exchange Reserves in India: A Co-integration Approach - Prabheesh. K P, Malathy. D and Madhumathi. R (2007). Published in: South Asian Journal of Management, Vol. 14, No. 2: pp. 36-46.

9. Confirmation Bias in Sequential Information Search After Preliminary Decisions: An Expansion of Dissonance Theoretical Research on Selective Exposure to Information - Eva Jonas, Stefan Schulz-Hardt, Dieter Frey, and Norman Thelen, Ludwig Maximilians-University

Journal of Personality and Social Psychology - 2001, Vol. 80, No. 4, 557-571.

10. Consumer-based decision aid that explains which to buy: Decision confirmation or overconfidence bias? Journal: Elsevier - Wee-Kek Tan, ChuanHoo Tan, Hock-Hai Teo.

11. Agostinelli, G., Sherman, S. J., Fazio, R. H., \& Hearst, E. S. (1986). Detecting and identifying change: Addition versus deletion. Journal of Experimental Psychology: Human Perception and Performance, 12, 445-454.

12. Anderson, J. R. (1991). The adaptive character of thought. Hillsdale, NJ: Erlbaum.

13. Anderson, J. R. (1991). Is human cognition adaptive? Behavioural and Brain Sciences, 14,471-517.

14. What Is Confirmation Bias and When Do People Actually Have It? - Author(s): Barbara Koslowski and Mariano Maqueda. Source: Merrill-Palmer
Quarterly, Vol. 39, No. 1, Invitational Issue: The Development of Rationality and Critical Thinking (January 1993), pp. 104-130 Published by: Wayne State University Press.

15. A Regret-Induced Status Quo Bias - Antoinette Nicolle, Stephen M. Fleming, Dominik R. Bach, Jon Driver, and Raymond J. Dolan - Wellcome Trust Centre for Neuroimaging, University College London.

16. Overcoming status quo bias in the human brain Stephen M. Fleminga,1, Charlotte L. Thomasa. B, and Raymond J. Dolana. Wellcome Trust Centre for Neuroimaging, University College London University of Bristol.

17. Rational choice with status quo bias - Journal of Economic Theory: Yusufcan Masatlioglu Department of Economics, New York University.

18. Status Quo Bias in Decision Making: Journal of Risk and Uncertainty - WILLIAM SAMUELSON - Boston University, RICHARD ZECKHAUSER Harvard University.

19. Equity Home Bias and Regret: An International Equilibrium Model - SSRN Journal

Bruno Solnik.

20. Individual decisions under risk, risk sharing and asset prices with regret - Christian Gollier University of Toulouse, Bernard Salani Columbia University.

21. Regret, disappointment and the endowment effect - Journal of Economic Psychology

Luis F. Martinez, Marcel Zeelenberg, John B. Rijsman.

22. Repurchase behavior of individual investors, sophistication and regret - Journal of Banking and Finance. Camille Magron, Maxime Merli LARGE Research Center, EM Strasbourg Business School, University of Strasbourg.

23. Limited attention and status quo bias - Journal of Economic Theory by Mark Dean, Ozgur Kibris and Yusufcan Masatlioglu.

24. A Regret-Induced Status Quo Bias - Antoinette Nicolle, Stephen M. Fleming, Dominik R. Bach, Jon Driver and Raymond J. Dolan. 